ENTREPRENEURSHIP AND SUSTAINABILITY ISSUES

ISSN 2345-0282 (online) http://jssidoi.org/jesi/ 2021 Volume 9 Number 2 (December) http://doi.org/10.9770/jesi.2021.9.2(6)
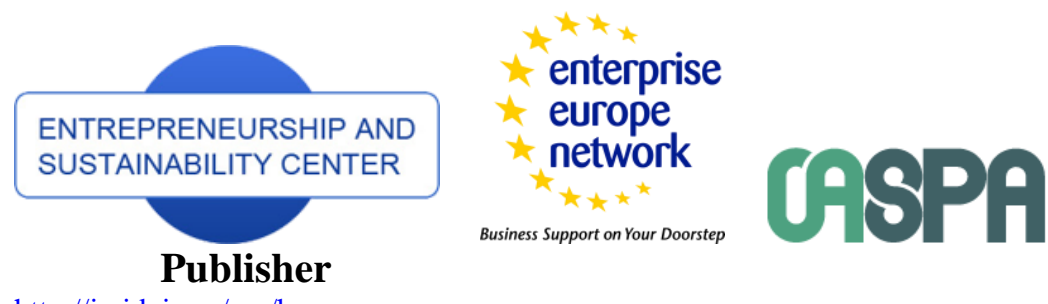

http://jssidoi.org/esc/home

Business Support on Your Doorstep

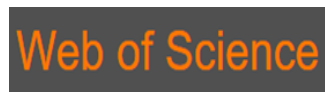

I) Clarivate

Analytics

\title{
FACTORS AFFECTING HOUSING CONDITIONS: A CASE STUDY OF CITTASLOW TOWNS IN POLAND
}

\author{
Agnieszka Napiórkowska-Baryla ${ }^{1}$, Natalia Świdyńska ${ }^{2}$ \\ ${ }^{1,2}$ Uniwersity of Warmia and Mazury in Olsztyn, Faculty of Economics, Olsztyn, Poland \\ E-mails: ${ }^{1}$ agnieszka.baryla@uwm.edu.pl; ${ }^{2}$ natalia.swidynska@uwm.edu.pl
}

Received 18 June 2021; accepted 15 October 2021; published 30 December 2021

\begin{abstract}
The concept of slow cities - "cities of good life" - promoted among small and medium-sized cities, results directly from the idea of sustainable development, which sets as a primary objective the reduction of poverty and increasing the standard and quality of life. The quality of life is understood as ensuring good housing conditions, access to services, health care and education, care for the natural and cultural environment, increasing economic activity and development with respect for spatial order and sustainable development principles. Housing conditions are one of the main determinants of the quality of life. Other decisions such as getting married, starting a family or changing jobs often depend on having adequate housing. The housing situation in Poland in comparison with the majority of EU countries is unfavorable, both in terms of the number of dwellings as well as their quality. Therefore, the aim of this research was to assess the housing situation and the factors influencing it in the towns associated in the Polish National Cittaslow Network in Warmińsko-Mazurskie Voivodeship. In the majority of cities, housing conditions were classified as medium or mediocre. Additionally, the cities were assessed in terms of their economic, demographic and investment potential, which made it possible to construct a synthetic index of their development. The level of the synthetic indicator was influenced most by the demographic, economic and investment situation. Moreover, a weak positive correlation was observed between the synthetic indicator and the housing situation. This means a weak influence of the synthetic indicator on the housing situation and vice versa. Demography in the examined Cittaslow cities influences the general development potential more strongly than housing. Therefore, city leaders should focus on creating instruments and solutions for improving demographic indicators. This is all the more justified, as the long-term forecast shows that this area may improve. This would make it possible to avoid threats resulting from deterioration of the economic and investment situation, and further on - housing.
\end{abstract}

Keywords: housing conditions; quality of life; Cittaslow network; sustainable development

Reference to this paper should be made as follows: Napiórkowska-Baryła, A., Świdyńska, N. 2021. Factors affecting housing conditions: a case study of Cittaslow towns in Poland. Entrepreneurship and Sustainability Issues, 9(2), 94-107. http://doi.org/10.9770/jesi.2021.9.2(6)

JEL Classifications: I31, J11, O12, O18 


\section{ENTREPRENEURSHIP AND SUSTAINABILITY ISSUES}

ISSN 2345-0282 (online) http://jssidoi.org/jesi/

2021 Volume 9 Number 2 (December)

http://doi.org/10.9770/jesi.2021.9.2(6)

\section{Introduction}

Housing conditions are among the determinants of living conditions and quality of life. Being among the most expensive durable consumer goods, a flat is usually high in the hierarchy of households' needs and priorities. It has a significant impact on the social environment, providing the base for proper living conditions. Housing availability - due to its immobility, high capital intensity, long period of return on investment and a relatively low adaptability to the user's needs, which vary in time and generally increase - makes it strategically important from the point of view of life quality and individual well-being.

Definitions of life quality treat it as a set of conditions of human life, objective attributes of the world of nature, things and culture, objectively evaluated human attributes related to one's living standard and social position, as well as the proper functioning of his/her body (Sęk 1993). However, a multidimensional analysis of life quality is more frequent (Kuc-Czarnecka 2019). Wejnert (2001) reports that, based on large samples, American scientists concluded that a subjective evaluation of life quality includes an analysis of 823 factors which reflect various aspects of a life situation. Further analyses helped to identify a set of factors, which was reduced to 123 life issues and subsequently, 30 inter-related groups of life issues were identified. Cummins (1996) analysed 27 definitions of life quality and found the majority of them to include five dimensions: emotional welfare (85\%), health (70\%), family and social relations (70\%), material wealth (59\%), a job and other forms of activity (56\%). Furthermore, many studies confirm that these areas are seen as the most important to the respondents. Further analyses revealed another two dimensions: confidence, safety and functioning in the community. Andrews and Inglehart (1979) show that four spheres of life: a job, family situation and income are of key importance to the global evaluation of members of the society.

The above shows that an evaluation of life quality should take into account mainly the basic factors, which include: economic conditions, housing conditions, free time, social security, human natural environment, health and social environment.

Compared to other EU countries, the housing situation in Poland is unsatisfactory, both qualitatively and quantitatively. This is shown in many publications and comparative statistics performed by Eurostat. This issue has been widely debated in the Polish literature, both with respect to developing effective housing policy (e.g. Cesarski 2013; Herbst 2013), and social housing policy (Lis 2011; Przymeński \& OliwaCiesielska 2014). Studies are conducted of the housing conditions of various social groups, e.g. young married couples (Korniłowicz 2003; Ulman \& Wałęga 2012) and elderly people (Zrałek 2012; Zubrzycka-Czarnecka 2012). Issues related to the housing standard, including the extent to which flats are equipped with infrastructure (Wilczek 2014; Janusz 2020) and housing deprivation (Napiórkowska-Baryła \& witkowska-Dąbrowska 2018) are also dealt with as well as financing the housing market (Bryx 2001; Główka 2012) and improving the availability of flats for rent (Urbańska 2008; Życiński 2008).

Housing quality is also the domain of the sustainable development concept. Global objectives of sustainable development with respect to housing were expressed most fully during the UN global conference on human settlements (Habitat II, Istanbul, 1996). At the same time, the "City Summit" was held there, at which it was pointed out that, at present, it is towns that shape the face of the earth and, therefore, implementing sustainable development on a global scale must start with the local and regional scale of the city (Alberti 1997). The New Urban Agenda was adopted at the Habitat III conference in Quito in 2016. Its section 1 presents a vision of cities and human settlements good for living, which: "fulfil their social function, including the social and ecological function of land, with a view to progressively achieving the full realization of the right to adequate housing as a component of the right to an adequate standard of living, without discrimination, universal access to safe and affordable drinking water and sanitation, as well as equal access for all to public goods and quality services in 


\section{ENTREPRENEURSHIP AND SUSTAINABILITY ISSUES}

ISSN 2345-0282 (online) http://jssidoi.org/jesi/ 2021 Volume 9 Number 2 (December) http://doi.org/10.9770/jesi.2021.9.2(6)

areas such as food security and nutrition, health, education, infrastructure, mobility and transportation, energy, air quality and livelihoods".

Alternative ways of everyday life and development are sought, particularly in the contemporary world, during the period of globalisation of the past 30 years, which is a source of many processes and phenomena, with quantity, speed and intensity being the main goals. Such opportunities are offered by towns developing according to the slow city concept. Towns, which "oppose the quantity-oriented to quality-oriented development, and replace rapid housing growth and location of large business entities with environment- and resident-friendly investments which guarantee "places of good living" based on endogenous development factors, often contrary to the globalisation trends in the economy and social life, including mass consumption" (Kaczmarek 2019). The slow city concept arises directly from the sustainable development concept, whose prime goal is to reduce poverty and to increase the standard and quality of life.

The concept of slow city and the global slow city movement and the Cittaslow network that grew out of it has its source in the idea of slow in various spheres of social and economic life, which has been promoted since the 1980s. The slow movement, which had its beginning in slow food, started to refer to the territorial dimension on various spatial scales: neighbourhood (slow housing), local (slow city), regional (slow region) and even global (slow planet) (Kaczmarek 2019).

Currently, the International Cittaslow Network (cities of good living) includes 272 towns in 30 countries, with 34 Polish towns, 25 of which are situated in Warmia and Mazury. The Polish National Cittaslow Network has two "supporting members" - the Warmińsko-Mazurskie Voivodeship and the District of Olsztyn ${ }^{1}$. This phenomenon has been described quite extensively in the literature - both Polish (Farelnik \& Stanowicka 2016, Farenik et al. 2021, Batyk \& Woźniak 2019, Kaczmarek 2019, Zadęcka 2017, Wierzbicka 2020) and foreign (Knox 2005, Mayer \& Knox 2006, Radstrom 2011). The idea of Cittaslow is part of the sustainable city concept, i.e. one in which the socio-economic goals are harmonised with issues of environmental conservation and energy use to ensure the continuity of change (Banachowicz \& Danielewicz 2006). It should be understood as increasing the population's wealth, improving the level of safety in a friendly social environment and constant improvement of the natural environment, as well as increasing the spatial order level and improving the functionality of urban spatial structures. The idea of the international Cittaslow movement involves promoting the culture of good and harmonious life in smaller towns, which is an alternative to the big-city bustle and globalisation. Towns-members of the Network make efforts to achieve the state of sustainable development, to create an urban policy which ensures proper relations between the economic growth, environment conservation and improvement of the residents' quality of life. Local authorities and local communities focus on: sustainable development of towns with the use of local resources, improvement of the residents' life quality by such measures as creating the proper urban infrastructure and places for leisure, environmental conservation and promoting pro-environmental attitudes among the population, caring about cultural values, restoration of monuments of architecture and the appearance of towns, propagating the culture of hospitality, as well as by a rich cultural offer for the residents and tourists, proper promotion of such assets, promotion of local products, craft and cuisine and elimination of architectural barriers for the disabled (Cittaslow Manifesto) ${ }^{2}$.

\section{Methods}

As was established, housing conditions are among the main determinants of living conditions. Therefore, the objective of this article is to assess the housing situation in Cittaslow towns in the Warmińsko-Mazurskie Voivodeship. The real estate market and the housing situation are affected by economic, socio-demographic, legal

\footnotetext{
${ }^{1}$ Cittaslow Manifesto https://www.cittaslow.org/content/association) 20.12.2020

${ }^{2}$ LIVE SLOW: a different side of modernity. Cittaslow Manifesto for the new humanism of being and living. Pdf. Downloaded from https://www.cittaslow.org/ 20.12.2020.
} 


\section{ENTREPRENEURSHIP AND SUSTAINABILITY ISSUES}

ISSN 2345-0282 (online) http://jssidoi.org/jesi/ 2021 Volume 9 Number 2 (December) http://doi.org/10.9770/jesi.2021.9.2(6)

and resource-related factors (Gawron 2011). At the first stage, the towns under study were assessed for their economic, demographic and investment-related situation, and the assessment results were then used to construct a synthetic development index, further in this paper referred to as the synthetic index. Subsequently, the effect of the synthetic index and its components on the housing situation was determined.

The Cittaslow network can include small and medium-sized towns ${ }^{3}$, which are in the greatest danger of depopulation (Lesińska \& Matuszczyk 2019; Śleszyński 2018). Therefore, a hypothesis was adopted that demographic factors have the greatest impact on the housing situation.

The demographic, economic, investment and housing situation was diagnosed by the statistical method. The 2010-2019 data for analysis were obtained from the Local Data Bank at the Statistics Poland. The analysis was performed for 23 units - Cittaslow movement members in 2019 situated in the Warmińsko-Mazurskie Voivodeship: ${ }^{4}$

- Seven urban communes: Bartoszyce, Górowo Iławeckie, Braniewo, Działdowo, Lubawa, Lidzbark Warmiński, Nowe Miasto Lubawskie,

- 15 urban areas within urban-and-rural communes: Bisztynek, Sępopol, Lidzbark, Ryn, Reszel, Orneta, Nidzica, Olecko, Barczewo, Biskupiec, Dobre Miasto, Jeziorany, Olsztynek, Pasym, Gołdap,

- One rural commune: Wydminy.

Ten indices, from two to five in each section, were defined and classified as stimulants (7) and destimulants (3) in order to determine which element - demographic, economic, investment situation - has the greatest impact on the synthetic index (Table 1) (Pieloch-Babiarz, 2020). The analysis was performed for urban communes, urban areas in urban-and-rural communes and one rural commune. This choice of the sample restricted the number of indices for analysis. The demographic situation was characterised by six partial indices, one of which (deaths per 1,000 residents) is a destimulant. A larger number of deaths contributed to a deterioration of the demographic situation. Among the factors with a positive impact included the number of marriages per 1,000 residents, the number of live births per 1,000 residents, population density, change of the population size per 1,000 residents and the working-age population in the total population. The economic situation was characterised by two partial indices, with the registered unemployed percentage being the destimulant and the number of business entities per 10 thousand residents being a stimulant. The number of unemployed in the whole commune was used in the urban areas of the urban-and-rural communes in the absence of data for the area under analysis. The percentage of the area covered by local plans in the total area and the percentage of legally protected area in the total commune area are two indices used to analyse the investment situation. The former is a stimulant and the latter is a destimulant. The proportion of the area covered by the local plans in the whole commune was used in the urban areas of the urban-and-rural communes in the absence of data for the area under analysis. To diagnose the housing situation, six partial indices were identified, four of which are stimulants: average flat floorage area, average flat floorage area per person, number of flats per 1,000 residents, average number of rooms in a flat and two destimulants: average number of persons per flat and average number of persons per room (Table 1).

\footnotetext{
${ }^{3}$ The classification adopted by Zadęcka (2018, p. 94), based on the population criterion, according to which small towns are those with a population of up to 20 thousand, medium-sized cities - those with a population of 20 to 100 thousand and big cities - over 100 thousand. ${ }^{4}$ Further towns in the Warmińsko-Mazurskie Voivodeship joined the network on 18 December 2020: Morąg and Szczytno, which were not included in this study.
} 
Table 1. The indices characterising the demographic, economic and housing situation

\begin{tabular}{|c|c|}
\hline Partial indices & S/D* \\
\hline \multicolumn{2}{|l|}{ Demographic situation } \\
\hline Marriages per 1000 people & $\mathrm{S}$ \\
\hline Live births per 1000 people & $\mathrm{S}$ \\
\hline Deaths per 1000 people & $\mathrm{D}$ \\
\hline Population density & $\mathrm{S}$ \\
\hline Change of population size per 1000 people & $\mathrm{S}$ \\
\hline Percentage of the working-age population in the total population & $\mathrm{S}$ \\
\hline \multicolumn{2}{|l|}{ Economic situation } \\
\hline Registered unemployed in total population & $\mathrm{D}$ \\
\hline Entities entered in the REGON database per 10,000 people & $\mathrm{S}$ \\
\hline \multicolumn{2}{|l|}{ Investment situation } \\
\hline The portions of the area covered by the local plans in the total area & $\mathrm{S}$ \\
\hline Proportion of legally protected areas in the commune area & $\mathrm{D}$ \\
\hline \multicolumn{2}{|l|}{ Housing situation } \\
\hline Average flat floorage area & $\mathrm{S}$ \\
\hline Average flat floorage area per person & $\mathrm{S}$ \\
\hline Number of flats per 1000 residents & $\mathrm{S}$ \\
\hline Average number of rooms per flat & $\mathrm{S}$ \\
\hline Average number of people per flat & $\mathrm{D}$ \\
\hline Average number of people per room & $\mathrm{D}$ \\
\hline
\end{tabular}

*S - stimulant; D - destimulant

Source: Prepared by the author based on the Local Data Bank

In order to avoid excessive internal correlations between indices, the coefficient of variation was used and variables with indices under 20 were excluded from the analysis. Further elimination of intercorrelated variables produced a variable correlation matrix and the reverse matrix method was used for the variable discrimination, with the diagonal elements of the matrix taking values from 1 to $\infty$. Their maximum level was taken as $\left(\widetilde{r}_{0} \leq 10\right.$ (Panek 2009). The variables above this value were eliminated from further analysis.

The study was performed by the taxonomic development measure of Z. Hellwig, which enables hierarchisation of the units with respect to their demographic, economic, investment and housing situation (see: Korzeb \& Niedziółka 2020, Piersiala 2019, Stec 2011, Świdyńska 2017). The higher the value of the index, the higher its development level (Klosa \& Widera 2017).

Based on the study findings, the units were ranked from the highest to the lowest development level depending on the demographic, economic, investment and housing situation and classified into four classes [Wysocki 2010].

- I: communes with a good situation:

- II: communes with a medium situation:

$$
d_{i} \geq \bar{d}_{i}+S_{d_{i}}
$$

$$
\bar{d}_{i} \leq d_{i}<\bar{d}_{i}+S_{d_{i}}
$$

- III: communes with a mediocre situation:

- IV: communes with a bad situation:

$$
\overline{d_{i}}-S_{d_{i}} \leq d_{i}<\bar{d}_{i}
$$


where:

$$
d_{i}<\bar{d}_{i}-S_{d_{i}}
$$

$d_{i}$ - synthetic measure calculated by the Hellwig development pattern method;

$\frac{d_{i}}{d_{2}}-$ arithmetic average of the synthetic measure $d_{i}$

$S_{d_{i}}$ - standard deviation of the synthetic measure $d_{i}$.

The relationship between the synthetic index made up of the indices that characterise the demographic, economic and investment situation, and the housing situation was measured by the Pearson linear correlation index.

The stepwise regression method, which allows for determining the most important variables of the set of explanatory variables that have an impact on the response variable, was applied to determine which of the elements affecting the synthetic index had the greatest effect on its level.

The next step involved the determination of the development prospects for the demographic, economic, investment, general (determined by the synthetic index) and housing situation. The current situation is likely to remain unchanged within the predictability horizon (Peitgen, et al., 2002). The logistic function, used to model various growth processes, was used in the study, according to which the growth rate decreases with time to reach the limit at the final phase. It was used in the study because of its good fit to the historical data. In order to apply it practically, it was modified by introducing three constant parameters which determined its course $-\mathrm{a}, \mathrm{b}$ and $\mathrm{c}$ (Grzegorek \& Wierzbicki 2009):

$$
y=\frac{\mathrm{a}}{1+\mathrm{b} \exp (-\mathrm{cxt})}
$$

where:

$\mathrm{a}, \mathrm{b}, \mathrm{c} \geq 0$,

a - saturation of the phenomenon, determined heuristically,

$\mathrm{b}, \mathrm{c}-$ function parameters selected by the statistic estimation.

The maximum development level estimated by the Hellwig development pattern is 1, which is why the parameter "a" was established at this level in the study. The statistic and analytical software STATISTICA and 2010-2019 data were used to calculate the $\mathrm{b}$ and $\mathrm{c}$ parameters of the logistic function, which were used to identify the development trends until 2029 and to create graphs for average values achieved for the units.

\section{Results}

The statistical verification results were used to choose those indices from the set determining the demographic, economic and investment situation (Table 1) that are characterised by a high coefficient of variance $(\mathrm{V}>20)$ and that are uncorrelated with each other $\left(\left(\widetilde{F}_{0}<10\right)\right.$. All the indices taken for analysis met those criteria. The Hellwig development pattern method was used to create indices which described the demographic, economic and investment situation in the units under study and they were grouped into four classes depending on their state.

The situation in the units under study in 2019 was the best in terms of the economic situation - it was good or medium in $60 \%$ of them. The investment situation was mediocre or bad in nearly $70 \%$ of them (Table 2). 
Table 2. The proportion of the units under analysis in individual classes in 2019, showing their demographic, economic and investment situation and the synthetic index

\begin{tabular}{|c|c|c|c|c|}
\hline & \multicolumn{3}{|c|}{ Situation } & \\
\hline Class & Demographic & Economic & Investment & Synthetic \\
\hline 1 - good situation & 13 & 17 & 13 & 9 \\
\hline $2-$ medium situation & 35 & 43 & 17 & 39 \\
\hline $3-$ mediocre situation & 39 & 22 & 65 & 39 \\
\hline $4-$ bad situation & 13 & 17 & 4 & 13 \\
\hline
\end{tabular}

Source: Prepared by the author based on research

The best demographic situation in 2019 was observed in Nidzica and the worst was in Sępopol. The best economic situation was in Sępopol and the worst was in Lidzbark. The best investment situation was observed in Dobre Miasto and the worst was in Lidzbark Warmiński. Only one unit was in the same demographic class Działdowo (class I) - throughout the period under analysis (2010-2019). High variance was observed in this regard for four units throughout the period under analysis and it manifested itself by the fact that they were categorised into each of the defined classes (Bisztynek, Olsztynek, Pasym and Sępopol). Units with a medium or mediocre demographic situation dominated during the period under study. Units with a low and high state accounted for the smallest share (Fig. 1).

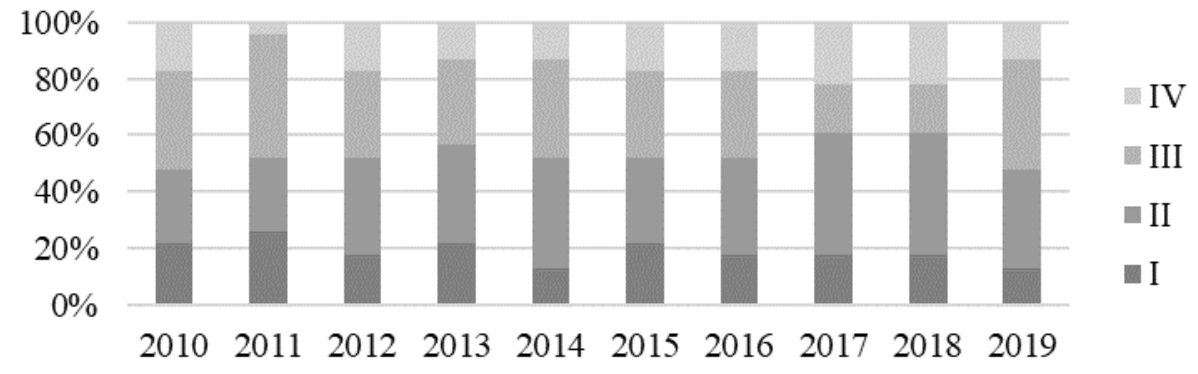

Fig. 1. Proportion of the units under analysis in individual classes in the years 2010-2019 with respect to the demographic situation Source: Prepared by the author based on research

The economic situation in the units under study was much more stable. Four units did not change their class during the 2010-2019 period: Olecko (I), Biskupiec and Lubawa (II), Nowe Miasto Lubawskie (IV). Steady improvement was observed in three units: in Górowo Iławeckie and Sępopol (from class IV, through III to II) and Orneta (from class III to II). Górowo Iławeckie and Sępopol are the only units which belonged to the largest number of classes during the analysed period (3). Units with a medium or mediocre economic situation dominated during the period under study. The proportion of units with good and bad situations was the smallest (Fig. 2).

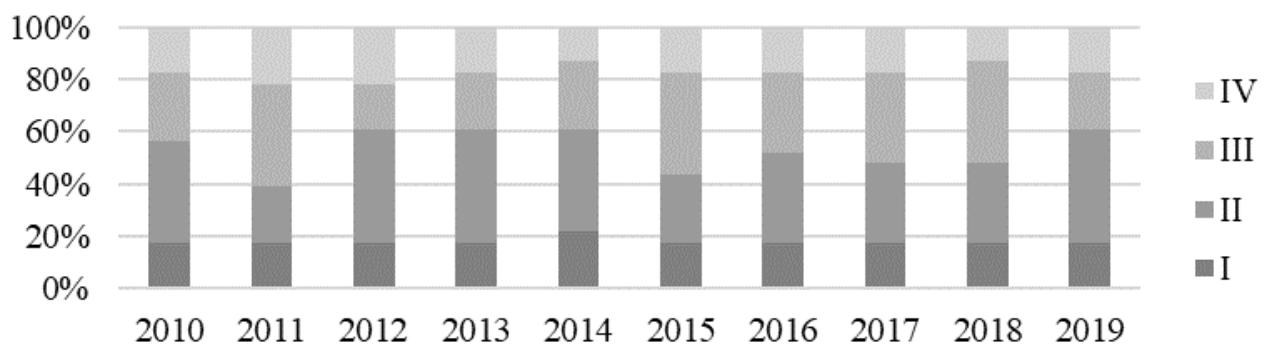

Fig. 2. Proportion of the units under analysis in individual classes in the years 2010-2019 with respect to the economic situation Source: Prepared by the author based on research 
The investment situation was highly stable. Only two units changed their classes during the period under analysis - Nowe Miasto Lubawskie from I to III and Lidzbark from II to III. Units with a mediocre investment situation dominated during the period under study. Those with a bad situation accounted for the smallest share (Fig. 3).

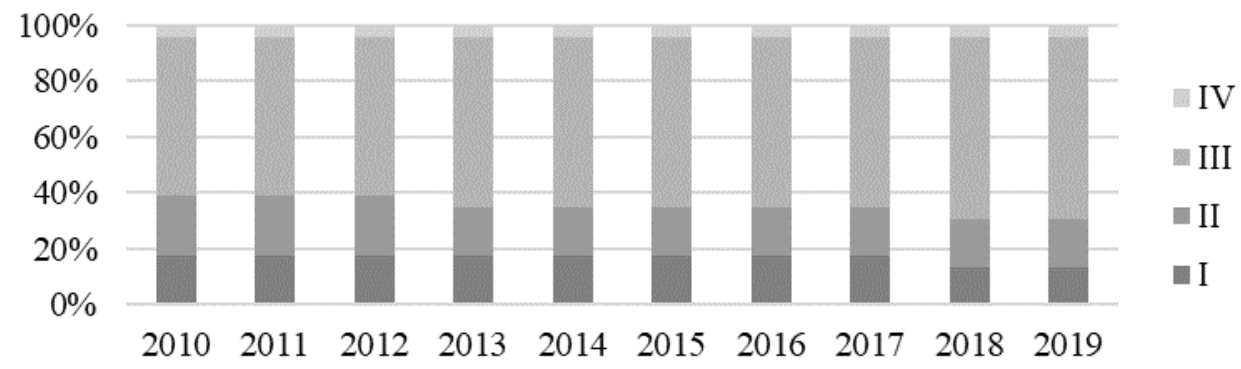

Fig. 3. Proportion of the units under analysis in individual classes in the years 2010-2019 for the investment situation Source: Prepared by the author based on research

An analysis of the synthetic index made up of partial indices which determine the demographic, economic and investment situation revealed high variability in the units under study. Only two of them (Wydminy and Olecko) were in the same class throughout the study (IV and II, respectively). The classification of two units (Lidzbark and Pasym) changed within the four classes during the 2010-2019 period. Classification of the largest number of units changed within three classes. The proportion of units in a medium and mediocre state dominated during the entire period. The number of units in the good and bad state was the smallest (Fig. 4).

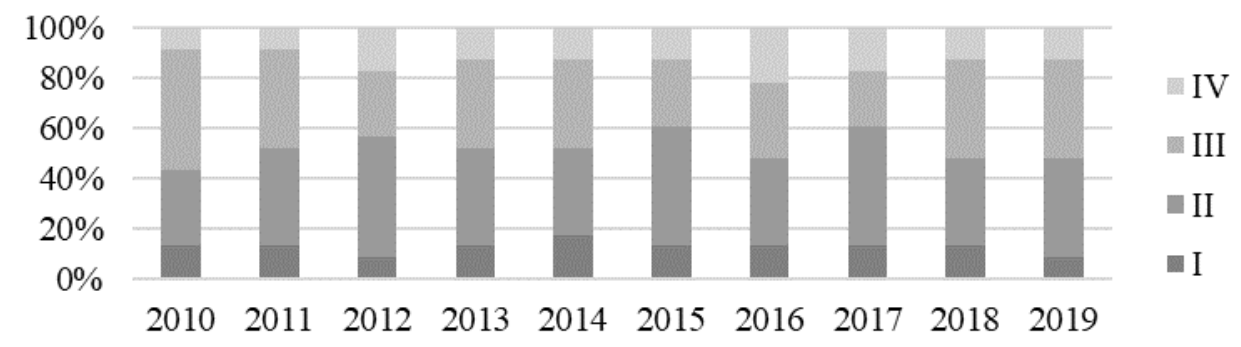

Fig 4. The proportion of the units under analysis in individual classes in the years 2010-2019 with respect to the general situation Source: Prepared by the author based on research

The stepwise regression method was applied to determine which of the elements that affect the synthetic index has the greatest impact on it. The model developed for all the units under study (2019 data) explained $99 \%$ of the synthetic index variance. The high multiple variance coefficient $(\mathrm{R}=0.99)$ indicates a strong link between the synthetic index and the three areas under study (the demographic, economic and investment situation). A high level of $\mathrm{F}$ and the corresponding level of test probability $\mathrm{p}$ confirmed a statistically significant linear relationship. The value of $\mathrm{t}$ showed that the absolute term and the regression coefficient differ significantly from zero.

The synthetic index level was affected to the greatest extent by: the demographic, economic and investment situation (Table 3). This relationship means that if the demographic situation improves by 1 , the synthetic index will increase by 0.81 ceteris paribus; if the economic situation improves by 1 , the synthetic index will increase by 0.38 ceteris paribus; if the investment situation improves by 1 , the synthetic index will increase by 0.26 ceteris paribus. 
Table 3. Significance of the synthetic index components

\begin{tabular}{|c|c|c|}
\hline Demographic situation & Economic situation & Investment situation \\
\hline 0.81 & 0.38 & 0.26 \\
\hline
\end{tabular}

Source: Prepared by the author based on research

The results of statistical verification were used to choose those indices from the set determining the housing situation (Table 1) that were characterised by a high coefficient of variance $(\mathrm{V}>20)$ and that were uncorrelated with each other $\left(\left(\widetilde{r}_{0} \leq 10\right)\right.$. Three variables were taken for analysis: average flat floorage area per person, number of flats per 1,000 residents and the average number of people per room.

The housing situation was good or bad in $9 \%$ of the units, it was medium in $43 \%$ of the units and mediocre in $9 \%$ in 2019. The housing situation was highly stable in 2010-2019. A change of class did not take place in 12 units they were in the same class throughout the study period. Changes in the other units took place within one class. Units with the medium or mediocre housing situation dominated throughout the period under study. The proportion of those with a low state was the smallest (equal to those with the high state from 2017 onwards) (Fig. 5).

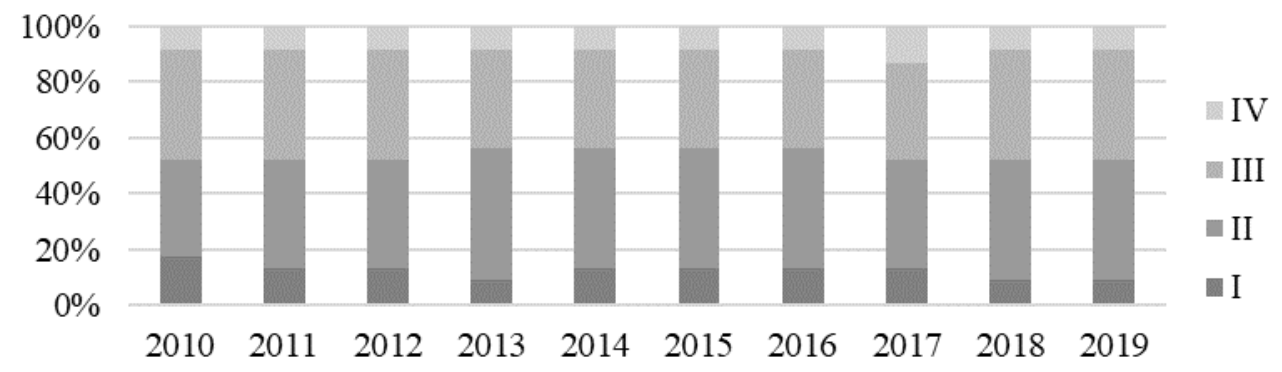

Fig. 5. The proportion of the units under analysis in individual classes in the years 2010-2019 with respect to the housing situation Source: Prepared by the author based on research

The Pearson linear correlation index calculated for the whole period under study indicates a weak positive correlation between the synthetic index made up of the indices that characterise the demographic, economic and investment situation, and the housing situation as measured by the Pearson linear correlation index. It was 0.33 in 2019 ( $\mathrm{p}=0.05$ ). This means that the synthetic index has a small impact on the housing situation and vice versa. 

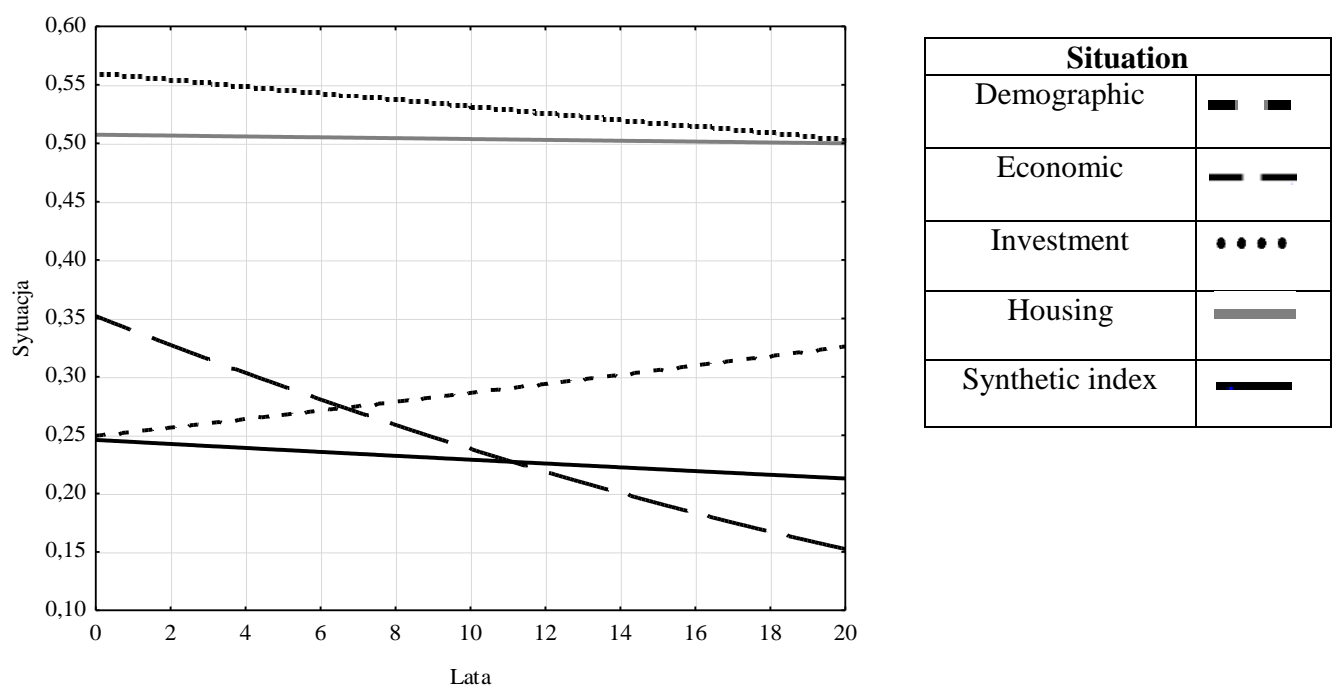

*0-10: 2010-2019 period; 11-20: 2020-2029 period;

Fig. 6. The state (2010-2019) and prospects for change (2020-2029) regarding the demographic, economic, investment and housing situation in Cittaslow units

Source: Prepared by the author based on research

Only the demographic situation will improve within the next 10 years. The economic and investment situation will deteriorate, with the deterioration being forecast as deeper in the economic situation. Ultimately, the synthetic index will get lower. The housing situation will be stable (Fig. 6).

\section{Conclusions}

Small towns are an important element of the settlement network in Poland. Those which belong to the Cittaslow network play a special role. Nearly $75 \%$ of them are situated in the Warmińsko-Mazurskie Voivodeship. They play a role in local development, for example, as centres of service provision, where business activities - mainly of a local range - are concentrated, and multi-functional centres. The use of local development potential and improvement of life quality plays an important role in slow city development strategies. Quality of life is understood as good housing conditions, access to services, healthcare and education, care about the natural and cultural environment, increasing business activity and development while respecting the spatial order and principles of sustainable development.

The aim of the study was to identify the economic, investment and demographic factors (potentials) and their impact on the housing conditions. The study findings show that the situation in the units under study was the best in terms of the economic situation - it was good or medium in $60 \%$ of them. The demographic situation was medium or mediocre in $74 \%$ of the units. The investment situation was mediocre or bad in nearly $70 \%$ of them. The synthetic index level, which was highly variable in the units under study, was affected to the greatest extent by: demographic, economic and investment situation, in that order. Moreover, a weak positive correlation was observed between the synthetic index (made up of the indices which characterise the demographic, economic and investment situation) and the housing situation. It means that the impact of the synthetic index on the housing situation and vice versa is small. It partially corroborates the hypothesis. Since demography in the Cittaslow towns under study has a stronger impact on the general development potential than housing, the town authorities should focus on creating tools and solutions aimed at improving the demographic indices. Creating socioeconomic conditions to encourage people to stay where they live and creating a migration policy to 


\section{ENTREPRENEURSHIP AND SUSTAINABILITY ISSUES}

ISSN 2345-0282 (online) http://jssidoi.org/jesi/ 2021 Volume 9 Number 2 (December) http://doi.org/10.9770/jesi.2021.9.2(6)

encourage return migration and to receive immigrants best suited to the local needs. It is particularly justified given the long-term forecasts, according to which there is going to be an improvement in the area. It would help to avoid threats arising from the deterioration of the economic and investment situation and, subsequently, the housing situation.

Significant changes are not forecast regarding the housing situation. However, it does not mean that nothing can be improved in this area. The index of 370 flats per 1,000 people in Poland is among the lowest in the EU countries. Shortage of flats for rent (including social flats) and their low availability, shown by a disadvantageous ratio of the price of $1 \mathrm{~m}^{2}$ to wages, are further factors with an adverse impact on the housing situation in Poland. Moreover, the overpopulation index, used in assessments of the flat quality, shows that $38.5 \%$ of the society live in overpopulated flats (with the EU average of 17.1\%). All of the indices considered regionally put the Warmińsko-Mazurskie Voivodeship in a worse position than the average in Poland (Napiórkowska-Baryła 2020). Probably, the situation in Cittaslow towns is similar. Therefore, it is an area in the social sphere which needs improvement. It is not possible without continuous dynamisation of the economic sphere and an increase in investment outlays, including in the public sphere. This will create an opportunity to achieve significant effects assumed in documents and strategies. The findings of a study conducted by Batyk \& Woźniak (2019) show that the residents of towns in the Cittaslow network in the Warmińsko-Mazurskie Voivodeship do not see any considerable benefits for the time being. Therefore, the conclusion is that joining the Cittaslow network was a strictly promotional action, aimed at acquiring funds from Cittaslow projects and advertising the towns by participation in various international events.

\section{References}

Alberti, M. (1997). Measuring Urban Sustainability. Environment Impact Assessment Review, 16 (4-6), 381-424.

Andrews, F.M., \& Inglehart, R.F. (1979). The structure of subjective well-being in nine western societies. Social Indicators Research, 6(1), 73-90. Retrieved from http://hdl.handle.net/ 2027.42/43699

Bryx, M. (2001). Financing of housing investments. Warsaw: Poltext Publishing House.

Cummins, R. (1996). The domains of life satisfaction. An attempt to order chaos. Social Indicators Research, 38, 303-328.

Banachowicz, B. \& Danielewicz, J. (2006). Co-governance as a factor of sustainable city development - the example of Łodz In J. Słodczyk \&D. Rajchel (Eds.) Sustainable development policy and city management instruments. Opole: Publishing Office of University of Opole.

Batyk, I., \& Woźniak, M. (2019). Benefits of belonging to the Cittaslow Network in the opinion of residents of member cities. Economic and Regional Studies, 12(1), 56-67. https://doi.org/10.2478 /ers-2019-0006

Cesarski, M. (2013). Housing policy in Poland in scientific works 1918-2010. Achievements and influence of the Polish school of research. Warszawa: Warsaw School of Economics.

Farelnik, E., \& Stanowicka, A. (2016). Smart City, Slow City and Smart Slow City as Development Models of Modern Cities. Olsztyn Economic Journal, 11(4), 359-370. https://doi.org/10.31648/oej.2938

Farelnik, E., Stanowicka, A., \& Wierzbicka, W. (2021). The effects of membership in the Polish National Cittaslow Network. Equilibrium. Quarterly Journal of Economics and Economic Policy, 16(1), 139-167. https://doi.org/10.24136/eq.2021.005

Gawron, H. (2011). Methods for evaluating the profitability of real estate investments. Poznan: Publishing Office of the Poznan University of Economics and Business.

Główka, G. (2012). System of financing residential property in Poland. Warsaw: Warsaw School of Economics. 


\section{ENTREPRENEURSHIP AND SUSTAINABILITY ISSUES}

ISSN 2345-0282 (online) http://jssidoi.org/jesi/ 2021 Volume 9 Number 2 (December) http://doi.org/10.9770/jesi.2021.9.2(6)

Grzegorek J., \& Wierzbicki A. (2009). New Statistical Approaches in the Systemic Analysis of Regional, Intra-Regionaland CrossRegional Factors of Information Society and Economic Development; the Case of Mazovia. Mazovian Regional Studies, 3, $117-128$.

Herbst, I. (2013). In search of a housing policy In Housing in the year of the family. Building Congress and Habitat for Humanity. Warsaw.

Janusz, M. (2020). The standard of living and its spatial differentiation among rural municipalities in Warmia-Masuria Province. Acta Scientiarum Polonorum Administratio Locorum, 19(4), 211-228. doi.org/10.31648/aspal.5687

Kaczmarek, U. (2019). The concept of Slow City and its implementation in small cities of the metropolitan area. The Example of Murowana Goślina and Schneverdingen. Regional Development and Regional Policy, 48, 119-145 https://doi.org/10.14746/rrpr.2019.48.08

Klosa, S., \& Widera K. (2017). Diversification of regions in terms of the level of innovation and entrepreneurship. Regional Barometer, 15(4): pp.77-83.

Knox, P.L. (2005). Creating Ordinary Places: Slow Cities in a Fast World. Journal of Urban Design, 10(1).

Korniłowicz, J. (2003). Housing situation of married couples in cities. Cracow; IRM Publishing Office.

Korzeb, Z., \& Niedziółka, P. (2020). Resistance of commercial banks to the crisis caused by the COVID-19 pandemic: the case of Poland. Equilibrium. Quarterly Journal of Economics and Economic Policy, 15(2), 205-234. https://doi.org/10.24136/eq.2020.010

Kuc-Czarnecka, M. (2019). Sensitivity analysis as a tool to optimise Human Development Index. Equilibrium. Quarterly Journal of Economics and Economic Policy, 14(3), 425-440. https://doi.org/10.24136/eq.2019.020

Lesińska, M., \& Matuszczyk K. (2019). The activity of regional authorities facing migration processes in the context of demographic changes: The case of three Polish voivodships. Regional and Local Studies, 3(77), 64-82. https://doi.org/10.7366/1509499 537704

Lis, P. (2011). Objectives and instruments of the social housing policy. In: J. Dzieciuchowicz (ed.) Contemporary transformations of the housing environment - selected problems. Łodz: Publishing Office of the University of Lodz.

LIVE SLOW: a different side of modernity. Cittaslow Manifesto for the new humanism of being and living, retrieved from https://www.cittaslow.org/ 20.12.2020.

Local Data Bank. https://bdl.stat.gov.pl/BDL/metadane

Mayer, H., \& Knox, P.L. (2006). Slow Cities: Sustainable Places in a Fast World. Journal of Urban Affairs, 28(4)

Napiórkowska-Baryła, A. (2020). Housing Resources in Poland - an Assessment Made in Terms of the Quality of Life. Annales Universitatis Mariae Curie-Skłodowska, section H-Oeconomia, 54(2), 67-76. https://doi.org/10.17951/h.2020.54.2.67-76

Napiórkowska-Baryła, A., \& Witkowska-Dabrowska, M. (2018). Housing deprivation in Poland - a regional approach. Baltic Geodetic Congress (BGC Geomatics. Olsztyn, 221-225. https://doi.org/10.1109/BGC-Geomatics.2018.00048

Panek, T. (2009). Statistical methods for multivariate comparative analysis. Warsaw: Warsaw School of Economics.

Peitgen, H.O., Jurgens, H., \& Saute, D. (2002). The limits of chaos. Fractals. Warsaw: PWN Publishing House.

Pieloch-Babiarz, A. (2020). Characteristics identifying the companies conducting different dividend policy: evidence from Poland. Equilibrium. Quarterly Journal of Economics and Economic Policy, 15(1), 63-85. https://doi.org/10.24136/eq.2020.004

Piersiala, L. (2019). The usage pattern of development method to assess the functioning of special economic zones: the case of Poland. Equilibrium. Quarterly Journal of Economics and Economic Policy, 14(1), 167-181. https://doi.org/10.24136/eq.2019.008

Przymeński, A., \& Oliwa-Ciesielska, M. (2014). Public housing assistance and the social demarginalisation of the poor. Poznan: Publishing Office of the Poznan University of Economics and Business

Radstrom, S. (2011). A Place-Sustaining Framework for Local Urban Identity: An Introduction and History of Cittaslow. Italian Journal of Planning Pratice, 1(44), 90-113. 


\section{ENTREPRENEURSHIP AND SUSTAINABILITY ISSUES}

ISSN 2345-0282 (online) http://jssidoi.org/jesi/

2021 Volume 9 Number 2 (December)

http://doi.org/10.9770/jesi.2021.9.2(6)

Sęk, H. (1993). Quality of life and health. Legal Economic and Sociological Movement, 2, 110-117.

Stec, M. (2011). Development conditions of voivodships in Poland - statistical and econometric analysis. Social Inequalities and Economic Growth, (20), pp. 232-251.

Szelągowska, A. (2011). Financing of social housing. Warsaw: CeDeWu Publishing Office.

Śleszyński, P. (2018). Poland of medium-sized cities. Assumptions and concept of deglomeration in Poland. Warsaw: Jagiellonian Club.

Świdyńska, N. 2017. Sustainable development of investment-attractive of warminsko-mazurskie province. Economics and Environment, 3(62), 50-60. https://doi.org/10.34659/2019/1/4

The New Urban Agenda - Habitat III (2017). retrieved from: https://habitat3.org/the-new-urban-agenda/ 20.12.2020.

Ulman P., \& Wałęga A. (2012). The Housing Situation of Young Couples in Poland. Social Inequalities and Economic Growth, (25), 126136. Rzeszow: Publishing Office of the University of Rzeszów. https://doi.org/10.15584/nsawg

Urbańska, W. (2008). Access to rental housing in European Union countries as a result of adopted housing policies. Urban Development Issues (2-3-4).

Wejnert, B. (2001). Problems of subjective and objective assessment of quality of life in American studies. In A. Wachowiak (ed.), How to live? Selected problems of quality of life. Poznan: Humaniora Foundation Publishing Office.

Wierzbicka, W. (2020). Socio-economic potential of cities belonging to the Polish National Cittaslow Network. Oeconomia Copernicana, 11(1), 203-224. https://doi.org/10.24136/oc.2020.009

Wilczek, T.M. (2014). Housing standard in Poland in comparison with neighbouring countries, members of the European Union. Studies in Economics- Research Papers of the University of Economics, (204), 195-209.

Wysocki, F. (2010). Taxonomic methods in recognizing economic types of agriculture and rural areas. Poznań: Publishing Office of Poznań University of Life Sciences.

Zadęcka, E. (2018). "Slow city" as a local development model. Economic and Regional Studies, 11(30), 84-106. https://doi.org/10.2478/ers-2018-0027

Zrałek, M. (2002). Residential environment of old people In: L. Frąckiewicz (ed.) Poland and Europe. Demographic processes and the threshold of the XXI century. The processes of aging of the Polish population and its social consequences. Katowice: Silesia Publishing Office.

Zubrzycka - Czarnecka, A. (2012). Urban policy against the aging of the city population - on the example of Poland, France and Canada. Problems of Social Policy. Research and Debates, 7(18)/2, 199-229.

Życiński, J. (2008). Prospects for the development of the rental housing market in Poland compared to foreign examples. Urban Development Issues (2-3-4). 


\section{ENTREPRENEURSHIP AND SUSTAINABILITY ISSUES}

ISSN 2345-0282 (online) http://jssidoi.org/jesi/ 2021 Volume 9 Number 2 (December)

http://doi.org/10.9770/jesi.2021.9.2(6)

Agnieszka NAPIÓRKOWSKA - BARYLA (PhD) is the assistant professor at the Faculty of Economics, University of Warmia and Mazury in Olsztyn, Poland. Research interests: housing, real estate management, quality of life, environmental economics.

ORCID ID: https://orcid.org/0000-0003-0434-1657

Natalia ŚWIDYŃSKA (PhD) is the assistant professor at the Faculty of Economics, University of Warmia and Mazury in Olsztyn,

Poland. Research interests: infrastructure, real estate management, environmental economics.

ORCID ID: https://orcid.org/0000-0002-1814-6679

Make your research more visible, join the Twitter account of ENTREPRENEURSHIP AND SUSTAINABILITY ISSUES: @Entrepr69728810

Copyright (C) 2021 by author(s) and VsI Entrepreneurship and Sustainability Center

This work is licensed under the Creative Commons Attribution International License (CC BY).

http://creativecommons.org/licenses/by/4.0/

(C) (†) Open Access 